\title{
Inequality and U.S. Society
}

\section{Citation}

Bobo, Lawrence D. 2010. Inequality and U.S. society. Du Bois Review: Social Science Research on Race 7(1): 30-34.

\section{Published Version}

10.1017/S1742058X10000123

\section{Permanent link}

http://nrs.harvard.edu/urn-3:HUL.InstRepos:5241394

\section{Terms of Use}

This article was downloaded from Harvard University's DASH repository, and is made available under the terms and conditions applicable to Other Posted Material, as set forth at http:// nrs.harvard.edu/urn-3:HUL.InstRepos:dash.current.terms-of-use\#LAA

\section{Share Your Story}

The Harvard community has made this article openly available.

Please share how this access benefits you. Submit a story.

Accessibility 


\section{Lawrence D. Bobo}

Department of Sociology and of African and African American Studies, Harvard University

Categorically Unequal: The American Stratification System, is a big, ambitious, toughminded, and carefully argued book. In a fashion, Princeton sociologist Douglas Massey sets out to answer the daunting questions of what are the fundamental mechanisms that lend recurrent patterning-social organization and structure, in a phrase-to social inequality in the United States. He unfolds a three-part answer. First, he sets out a basic theoretical framework for understanding the process of social stratification: the factors and mechanisms to which we must attend in order to understand how people come to be systematically allocated to positions of differential reward and status. This section of the book is heavily indebted to Charles Tilly (1998). Part of what Massey does here is quite conventional within sociology, so much so that he rightly refers to it as invoking "stratification's Holy trinity": namely, he points to the dividing lines of race, class, and gender. Yet, part of what he does 
here-or at least how he does it—strikes me as quite unusual for sociologists: namely, he says that in order to understand social stratification you must attend in some detail to foundational notions from social psychology. To wit, attention to institutional practices and macro-level process are insufficient to provide a robust sociology of the dynamics of inequality.

Second, Massey develops an overview, mapping the current topography of inequality with regard to core economic measures. This part of the work is probably the least likely to generate contention and what matters most about it, in any event, is really played out in fuller detail as part of the third task which Massey sets for himself. Third, he then fleshes out in great detail the dynamics of inequalities of race, of class, and of gender with an emphasis on the post-World War II period.

For sociologists, as Massey explains, "stratification refers to the unequal distribution of people across social categories that are characterized by differential access to social resources" (p. 1). The resources might be economic in the form of income or wealth. They might be status related involving prestige or other symbolic claims. And they might even be socioemotional. (I assume that power and access to power resources, legitimate and otherwise, is included here, though he does not say so explicitly.) Drawing on Tilly's durable inequality formulation, Massey suggests that stratification processes entail two basic mechanisms: (1) "the allocation of people to social categories"; and (2) "the institutionalization of practices that allocate resources unequally across these categories" (pp. 5-6). These institutionalized practices involve exploitation and opportunity hoarding.

Critically, the process rests on the human cognitive capacity, and indeed proclivity, to categorize. "In a very real sense," Massey writes "stratification begins psychologically with the creation of cognitive boundaries that allocate people to categories. Before categorical inequality can be implemented socially, categories must be created cognitively to classify people conceptually based on some set of achieved and ascribed characteristics" (p. 8). At this point, some students of social stratification may wonder exactly how much social psychology does a good sociologist really need to know, for Massey does not stop here. Moreover, he does not even turn in the direction of a more familiar social psychological model of social stratification, namely the Wisconsin status attainment model, wherein interaction with and the influence of significant others in one's life helps to shape aspirations and related patterns of behavior that intervene in between parental socioeconomic status and a child's own educational and early occupational attainments (Sewell and Hauser, 1980).

No, Massey turns at this point to eminent social psychologist Susan Fiske's work on stereotyping and prejudice and even delves a bit into the emerging field of cognitive neuroscience (Fiske 1998; Fiske et al., 2002). The upshot of this manuver is that all of us, "whether [we] think of [ourselves] as prejudiced or not, hold in [our] heads schemas that classify people into categories based on age, gender, race, and ethnicity. [We] cannot help it. It is part of the human condition, and these schemas generally include implicit memories that yield subconscious dispositions toward people and objects, leading to stereotypes" (pp. 10-11). Critical here is the claim that these stereotypes are not merely associations of category memberships with various positively or negatively valued traits or attributes. There are two evaluative dimensions at work that lead us to array members of groups in a two-dimensional space. Those dimensions are warmth, on the one hand, and competence on the other. The result is a core set of four-ideal types linking groups to a central socio-emotional predisposition toward them: such as pity for those viewed as warm but not particularly competent (classic chauvinist, paternalistic male orientation to women); envy toward those viewed as highly competent but not very warm (as perhaps best epito- 
mized by the conspicuous Asian success at certain elite institutions of higher learning); we tend to despise those understood as neither warm nor competent (we need only think of radio personality Don Imus's hateful remarks about the Black women of the Rutger's basketball team in 2007 as "nappy headed hos" ); and lastly those who we hold in high esteem as both warm and competent, the privileged classes.

I find myself very much in agreement with this set of framing moves by Massey. I think it important for students of social stratification, and especially for those interested in understanding racial inequality. Let me say several things about Massey's treatment of race and a changing but remarkably durable racial divide. First, BRAVO! I'm in near complete agreement with the argument he sketches out, both with respect to the contemporary presence of discrimination in many key domains of life and the extent to which such bias rests upon negative stereotyping and racial prejudice. Yet, second, there are important ways that his argument is incomplete or insufficiently complex and nuanced. Part of this traces, no doubt, to the enormity of the terrain he had to cover in a relatively compact treatment. However, to elaborate a bit, more could have been folded in to capture just how much more complex the terrain is today. In the process of documenting continuing discrimination in the housing market, in insurance markets, in car sales, and in the erection of a vast racialized, mass-incarceration society, Massey's treatment actually short changes the vast differences in accumulated wealth linked with race (Oliver and Shapiro, 1995). The profoundly sedimentary character of this dimension of economic status and resources is critical to an individual or family's capacity to maintain a particular standard of living. Incorporating a more substantial discussion of wealth inequality would not reverse any aspect of Massey's argument, but it would serve to reinforce and deepen an appreciation for how race still structures overall quality-of-life experience.

Now, let me say something a little more contradictory. Because of the emphasis on major patterns of racial inequality and the contemporary relevance of discrimination, the changing nature of the racial divide itself and the class complexity of Black America are given short shrift in Categorically Unequal. That is, to say that Blacks have lower odds of a call back from an employer or realtor, or that a White car salesman is likely to hold out for a higher price from a Black buyer, especially a Black male buyer versus a White male, is not to say that the sort of absolute categorical distinctions evident in the slavery and Jim Crow eras operates today. Massey certainly acknowledges the more subtle, complicated, and indirect ways in which discrimination now operates. But one feels the need to see more detail on how this plays out at different points in the class structure than Massey ever provides. Thus, for example, Bruce Western's (2006) analysis of the rise in incarceration is careful to stress the extent to which this has involved class and race, falling with special severity on high school-dropout Black men. We could use some consideration of the dynamic of racial discrimination at the higher end of the class distribution as well, but we find relatively little of it. This is important to do because it is too easy for some analysts to dismiss the evidence of on-going discrimination by pointing to the attainments of the Black middle class (Thernstrom and Thernstrom, 1997). The very powerful and convincing auditing studies can be read as establishing that the hurdles Blacks face in finding employment are somewhat harder-neither completely categorical nor impassable, just harder. Could such problems be solved perhaps, some might ask, with a little more effort or more diligence in school?

This concern about nuance and complexity in the argument can be raised in regard to Massey's discussion of Latinos being fashioned into a new, increasingly racialized underclass. He shows that changes in immigration policy have worked to 
reduce the status of Latinos-a group that once occupied a sort of liminal status in between Black and White-to a point where they increasingly come to resemble Blacks on key economic indicators. The problem here is that crucial distinctions regarding citizenship status, generational status, and other factors such as English language mastery are not uniformly taken into account in making these comparisons. My point is not that Massey's claims are wrong-but one immediately wants to know how robust some claims are in the presence of controls for these sorts of other factors. We know from other careful research that these patterns are quite robust (Telles and Ortiz, 2008).

Likewise, the nuance and complexity concern arises in the final chapter as well where Massey does attempt some analysis of race, class, and gender simultaneously. Such integrated analyses of race-, class-, and gender-dynamics are never easy and we have few powerful exemplars in the sociological literature (Jackman 1994). For Massey, this part of the analysis proceeds mostly with respect to explaining individual and family earnings, specifying main effects for the 'holy trinity' or interactive ones. Again, he provides a useful but very gross cut on how these factors intertwine. Thus, one suspects a more specific face could be put on some of the extreme points in the continuum, comparing an undocumented recent Latina immigrant at one extreme, to an Ivy-league educated legacy-admit White male at the other. To his credit, Massey does specify the extent to which inequality has grown and identifies formal education as an increasingly central mechanism allocating people to relative privilege or disadvantage. Access to education and its quality, of course, are also, Massey notes, very much class- and race-stratified.

Third, the whole project has more the feel of a powerful typology and descriptive account, than it does an explanatory or predictive model. The clear specification of an engine or driver to change is largely absent, having been left as implicit. Namely, Massey seems to suggest that people act in ways that are consistent with their underlying stereotypes and schemas and, furthermore, that there is a certain inertia attached to established institutional practices. In fairness, much great sociology does not reach beyond excellent typologizing and thick description. But I think more is possible here. Let me give just a quick teaser: I am very much attracted to the notion of boundary work as Massey uses it. Accordingly, "Boundary work involves actions and behaviors undertaken to differentiate people socially; they are publicly labeled as members of an in- or out-group who thus embody the social traits associated with that category of people. Labeling may occur through informal mechanisms such as gossip, ridicule, shaming, ostracism, praise, or harassment that serves to 'put people in their place,' or it may be effected formally through regulations and laws such as the one-drop rule and the anti-miscegenation laws enacted throughout the South before the civil rights era. Boundary work distinguishes people from one another socially by highlighting interpersonal differences across categorical lines" (p. 244).

I have also been a long-time advocate for the notion of prejudice as a sense of group position, a view of prejudice with unambiguous sociological pedigree (Blumer 1958; Bobo and Tuan, 2006). To wit, many of the great struggles of the past, over school desegregation and affirmative action, let's say, can be read as boundary struggles where the fight really was very much over changing, or resisting change to customary group positions in access to key social resources of educational and job opportunities. The politics of these struggles, a great body of literature shows, is directly and deeply linked to things we would rightly classify as racial prejudice and its social dynamics.

The importance of Massey's work springs from what we all know: inequality has widened enormously in this country over the past several decades. The growing gap 
between the haves and have-nots here in the United States, while certainly linked to large-scale processes of globalization and technological innovation, is not a simple mechanical function of such externalities. Nor is the rise in Black incarceration the inevitable product of a society's age-old struggle to deal with "unruly men;" just as the declining fortunes of undocumented immigrants in particular, and segments of the Mexican American community more generally, reflect policy choices and actions, not some inevitable macro-social dynamic. Sociologists need theoretical models that involve the full specification of these critical micro- and meso-level processes that undergird social inequality. With Categorically Unequal, Massey has provided a strong provocation and analytical push in the direction of a more comprehensive sociology of stratification processes.

Corresponding author: Professor Lawrence D. Bobo, Department of Sociology, William James Hall, 33 Kirkland Street, Cambridge, MA 02138. E-mail: bobo@ wjh.harvard.edu

\section{REFERENCES}

Blumer, Herbert (1958). Prejudice as Group Position. Pacific Sociological Review, 1: 3-7.

Bobo, Lawrence D. and Mia Tuan (2006). Prejudice in Politics: Group Position, Public Opinion, and the Wisconsin Treaty Rights Dispute. Cambridge, MA: Harvard University Press.

Fiske, Susan T. (1998). Stereotyping, Prejudice, and Discrimination. In Daniel T. Gilbert, Susan T. Fiske, and Gardner Lindzey (Eds.), The Handbook of Social Psychology, $4^{\text {th }}$ ed., pp. 357-415. New York: McGraw Hill.

Fiske, Susan T., Amy J. C. Cuddy, Peter Glick, and Jun Xu (2002). A Model of (Often Mixed) Stereotype Content: Competence and Warmth Respectively Follow from Perceived Status and Competition. Fournal of Personality and Social Psychology, 82 (6): 878-902.

Jackman, Mary R. (1994). The Velvet Glove: Paternalism and Conflict in Gender, Class, and Race Relations. Berkeley, CA: University of California Press.

Oliver, Melvin L. and Thomas M. Shapiro (1995). Black Wealth/White Wealth: A New Perspective on Racial Inequality. New York: Routledge.

Sewell, William H. and Robert M. Hauser (1980). The Wisconsin Longitudinal Study of Social and Psychological Factors in Aspirations and Achievements. In Alan C. Kerckhoff (Ed.), Research in Sociology of Education and Socialization, Vol. 1, pp. 59-99. Greenwood, CT: JAI Press.

Telles, Edward E. and Vilma Ortiz (2008). Generations of Exclusion: Mexican Americans, Assimilation, and Race. New York: Russell Sage Foundation.

Thernstrom, Stephan and Abigail Thernstrom (1997). American in Black and White: One Nation, Indivisible. New York: Simon \& Schuster.

Tilly, Charles (1998). Durable Inequality. Berkeley, CA: University of California Press.

Western, Bruce (2006). Punishment and Inequality in America. New York: Russell Sage Foundation. 